Farum

Sociológico

\section{Forum Sociológico}

Série II

31 | 2017

Transition to work of graduates in Southern Europe:

Crisis and new challenges

\title{
Degrees of precariousness : the problematic transition into the labour market of Greek higher education graduates
}

Graus de precariedade : a problemática inserção profissional dos diplomados de ensino superior

Spyros Themelis

\section{OpenEdition}

Journals

Electronic version

URL: https://journals.openedition.org/sociologico/1811

DOI: 10.4000/sociologico.1811

ISSN: 2182-7427

Publisher

CICS.NOVA - Centro Interdisciplinar de Ciências Sociais da Universidade Nova de Lisboa

Electronic reference

Spyros Themelis, "Degrees of precariousness : the problematic transition into the labour market of Greek higher education graduates", Forum Sociológico [Online], 31 | 2017, Online since 31 December 2017, connection on 31 March 2022. URL: http://journals.openedition.org/sociologico/1811 ; DOI: https://doi.org/10.4000/sociologico.1811 


\title{
DEGREES OF PRECARIOUSNESS: THE PROBLEMATIC TRANSITION INTO THE LABOUR MARKET OF GREEK HIGHER EDUCATION GRADUATES GRAUS DE PRECARIEDADE: A PROBLEMÁTICA INSERÇÃO PROFISSIONAL DOS DIPLOMADOS DE ENSINO SUPERIOR NA GRÉCIA
}

\author{
Spyros Themelis \\ University of East Anglia, School of Education and Lifelong Learning
}

\begin{abstract}
This paper discusses the transition into the labour market among higher education graduates from 2000 to date. It identifies a number of trends. First, this transition is protracted and not completed for the majority of Greek graduates until their thirties. Second, the labour market is fragmented along education level, place of living (urban or non-urban), gender, age and ethnic lines. Third, higher education does not seem to play a socially integrative role, as it does not shield against unemployment, emigration and precariousness. Fourth, the economic crisis has exacerbated enduring problems integral to the labour market and its weak connections with higher education. The multiple and overlapping problems underlying the transition from higher education to the labour market is at the crux of the economic and political problems Greece is facing and they point to a ticking bomb at the foundations of the Greek society.
\end{abstract}

Keywords: labour market, Greece, higher education, precarity

\begin{abstract}
Resumo
Neste artigo discute-se a transição para o mercado de trabalho de graduados do ensino superior, desde o ano 2000 até ao presente, identificando-se um conjunto de tendências. Em primeiro lugar, essa transição é prolongada e não completa para a maioria dos graduados gregos até 30 anos de idade. Em segundo lugar, o mercado de trabalho é fragmentado em função do nível de escolaridade, do local em que se habita (urbano ou não urbano), do género, da idade e da origem étnica. Em terceiro lugar, o ensino superior não parece preencher completamente o papel de inclusão social, pois não permite evitar o desemprego, a emigração e a precariedade. Em quarto lugar, a crise económica terá contribuído para exacerbar problemas duradouros do mercado de trabalho e das suas fracas ligações com o ensino superior. Os problemas múltiplos e sobrepostos subjacentes à transição do ensino superior para o mercado de trabalho estão no cerne dos desafios económicos e políticos enfrentados pela Grécia e apontam para uma bomba relógio que pode atingir os alicerces da sociedade grega.
\end{abstract}

Palavras-chave: mercado de trabalho, Grécia, ensino superior, precariedade

\section{Introduction}

Transition issues facing Greek graduates are explained through the traditional orientation of higher education towards the public sector (Kanellopoulos et al., 2003) but also through the mismatch between the production of graduates and the labour market capacity to absorb them (Karamessini, 2008; Liagou- ras et al., 2003). Using aggregate data from various sources, but mainly from Eurostat and OECD, this paper explores these key issues and their ability to account for transition difficulties especially among young graduates. The findings discussed point to a radical shift within the labour market and employment conditions between pre- and post-crisis Greece. The underlying trend is that of "precarianisation" 
(Standing, 2011), that is to say of the creation of a more flexible labour market and a workforce to match it. The paper's focus is from 2000 to date, so it covers a sufficient and almost equal amount of time before and after the global economic crisis that broke out in 2008.

It starts with the presentation of some key trends regarding the overall education situation in Greece from the dawn of the new millennium to date and especially of the increase in tertiary education. It then moves on to discuss the employment and labour market changes before and after the deep recession it entered since 2009 and the bailout agreements it has signed in 2010. In the third section, the paper discusses the repercussion of the transformations in the labour market for new higher education graduates, their prospects and alternative avenues to "precarity". Finally, in the conclusion I discuss the implications of these findings both for Greek graduates but also for the country itself.

\section{Educating the precariat: higher Education access and attainment}

In this section, we discuss the evolution of higher education (HE) access and attainment in Greece (approximately from the new millennium up to the present) in order to highlight differences in key indicators but also to report on any progress that might have been achieved before and after the crisis.

Before the crisis, education attainment in the wider population was rapidly improving. Between 1997 and 2009 alone, higher education graduates in the $25-64$ year-old group increased by $8 \%$ (from $16 \%$ to $24 \%$ ), upper secondary school qualification holders by $9 \%$ (from $29 \%$ to $38 \%$ ) and non-completion rates for upper secondary education reduced by $17 \%$ (from $56 \%$ to $39 \%$ ) (OECD, 2011). Although $\mathrm{HE}$ attainment rates for the overall population continued to rise during the years of the crisis, the pace of increase was slower than before. In 2015, 28\% of 25-64 year olds held a qualification equivalent to a degree or higher ${ }^{1}$ (OECD, 2015). Expectedly, $\mathrm{HE}$ attainment rates improved somewhat more rapidly for the 25-34 year-old group with much of the improvement taking place after 2009 (the year held to coincide with the onset of the Greek crisis). However, HE rates were already low (23,9\% in 2000, compared to $25,9 \%$ for the OECD countries) leaving, therefore, a lot of room for improvement. Indeed, the expansion of Greek HE that has been realised after 2009 benefited the 25-34 year-olds more than any other age group. Despite the deep recession, as of 2015, Greece managed to meet its HE attainment target of $40 \%$. In $2015,40,1 \%$ of the said group were in $\mathrm{HE}$, marking a steep increase by over $16 \%$ in the 2000-2015 period and placing Greece beyond the European Union average $(38,7 \%)^{2}$. Despite the marked progress in accessing $\mathrm{HE}$, Greece still has one of the lowest completion rates among its EU and OECD counterparts. In 2000 completions stood at $54 \%$ with an OECD and EU average of $76 \%$ and $77 \%$ respectively. In 2011 , this rate rose to $68 \%$ for Greece but it was still lagging behind the EU and OECD average (both at 83\%) (OECD, 2013).

What is more, the Greek HE system displays considerable inequalities by gender and country of origin. The gender HE attainment gap in 2015 $(10,2 \%)$ was slightly above the EU28 average $(9,4 \%)^{3}$ but substantially more augmented than in 2012 (6\%). Indisputably, policies implemented during the crisis have had a negative impact on reducing inequalities in gender attainment. The same trend is manifest in the rest of the EU countries with the exception of Ireland. Inequalities of attainment are even more pronounced in relation to country of origin ${ }^{4}$. In comparison to its EU counterparts, Greece has one of the lowest HE attainment rates for non-natives, 8,4\%, compared to an EU average of $28,6 \%$.

In terms of general versus vocational education, Greece has traditionally maintained a strong emphasis on general education and a marginal focus on tertiary level Vocational Education and Training (VET). The latter has been characterized by chronic underfunding and low effectiveness of any links between the national education and training systems with the labour market (Cedefop, 2011). At any rate, both general education and training have been strongly affected by very low and decreasing public spending, due to the strict fiscal consolidation imposed since 2010. Although the ratio of expenditure to GDP did not alter significantly between 2008 and 2013 , overall spending on education decreased by at least $25 \%{ }^{5}$ given the cumulative reduction in GDP of equal proportion ( $25 \%$ ) during this time period.

\section{The employment and labour market situation of the precariat}

Section one showed that the overall education level among the wider population, especially the younger ones, has increased substantially over the last two decades or so. But do higher educational qualifications secure their incumbents better employment prospects? In this section, I discuss some qualitative and quantitative changes in the employment and labour market situation of young HE graduates.

Cementing precarity: public versus private sector employment

Perceptions about employment security and prestige have drastically changed with the onset of the crisis. While in the past young graduates used 
to pursue public sector occupations, after the crisis their preferences, or forced choices to be more precise, have shifted to the private sector. According to a recent survey (kariera.gr, 2016) among the so called Generation Y, that is to say those born between 1980 and 2000,73\% prefer to work in the private sector, $9 \%$ want to set up their own start-up company and only $8 \%$ prefer to work in the public sector $^{6}$. The low esteem in which young adults hold public sector occupations is explained by the drive to increase flexibility at any cost and in every direction as attested to by the wage compression experienced by public servants, job loss or fear of job loss and the deteriorating working conditions within the sector. In other words, the "precarianisation" of the labour market has affected worse the public sector, which has matched and in some cases surpassed in terms of flexibility, instability and uncertainty in employment situation of its workforce the private sector.

In a drive to increase "wage flexibility" (Standing, 2011), "Greece experienced one of the largest falls in real wages among the OECD countries (more than $5 \%$ per year on average since the first quarter of 2009). The private sector was hit hard by wage cuts (-3,4\% per year)." (OECD, 2014: 1). According to other estimates, reduction in public sector wages was at least 35\% between 2010 and 2013 alone. Even occupations which have always been associated with modest remuneration, such as teaching, received a pay cut of $17 \%$ only between 2009 and 2011 (in comparison to a $2 \%$ average drop in the OECD countries) (OECD, 2013).

Owing to the bailout packages Greece has signed with its lenders since 2010, workers were not only to lose out on wages but their labour was now to be valued less than ever before:

\footnotetext{
"the reforms have led to a dramatic decline of the labour cost as a result of wage cuts. The minimum wage has fallen by $20,8 \%$ between 2009 and 2012, while the cumulative reduction of the real unit labour cost reached $12,2 \%$ between 2010 and 2012. Overall, the total contraction of the average nominal wage in the Greek economy for the period 2010-13 will reach $30 \%$, bringing down nominal wages to 2000 levels and real wages to 1996 levels." (European Parliament, 2013: 6).
}

Apart from wage contraction, public sector workers have been hit by pension system reforms. While after the crisis early retirement has been pursued as a route of escaping the deterioration of working conditions, a new system of calculating pension contributions has resulted in the vast majority of public workers taking a cut to their pensions and a net loss of future income for thousands of others still in employment.
The other tentacle of precarianisation, "numerical flexibility" (Standing, 2011), was implemented through job losses, which were brought about in three ways, namely through non-renewal in temporary contracts, early retirement and redundancies (Zahariadis, 2014). Between 2010 and 2013, it is estimated that the Greek state removed approximately $20 \%$ of its workforce from its payroll either through redundancies or voluntary retirement (from 768,009 in 2010, to 618,709 in 2013). This number represents a sharp drop in the total amount of public sector workforce, especially if we also take into consideration the recruitment freeze that has been implemented since $2010^{7}$. The tough conditions in the public sector ought not to conceal the even worse situation in the private. A recent study found that in the 2009-2014 period, the private sector took the lion's share in terms of job losses and wage cuts and that "employment loss in the private sector has been almost twice as high as that in the public sector." (Christopoulou and Monastiriotis, 2016), further entrapping young graduates into precarity.

The employment of the precariat

In order to appreciate the degree of this precarity of Greek graduates, we will intersperse some selected comparisons between their labour market prospects and those of their EU and OECD counterparts. Between 2003 and 2007, average unemployment rates among HE graduates (males and females aged 20-34 years) in the EU stood at $7,1 \%$. This rate compares favourably to secondary education graduates who displayed much higher unemployment rates $(10,9 \%)$ (EENEE, 2012) ${ }^{8}$. Regarding employment among 20-34 year olds, the reverse pattern is evident. That is to say, employment in the EU was steadily rising until the onset of the crisis when it peaked at $82 \%$ in 2008 . Since then, it has been decreasing and in 2013 it reached a low of $75,4 \%$, before it started increasing again (76,9\% in 2015). One of the most notable exceptions is Germany, where graduate employment has been traditionally at very high levels (79,6\% in 2005) and rising even amidst the crisis (from $86 \%$ in 2010 to $90,4 \%$ in 2015).

By contrast, Greece, along with other countries from the periphery (namely Italy, Spain, and Portugal) has been displaying higher rates of graduate unemployment than the EU average. Arguably, HE qualifications in the EU periphery do not confer high employment prospects to their graduates and, when they do, the associated advantages are marginal in comparison to those enjoyed by secondary education graduates (EENEE, 2012). In other words, $\mathrm{HE}$ qualifications in these countries do not lead to improved employment prospects nor do they provide protection to their incumbents from unemployment. 
More specifically, the employment situation before the crisis provided a challenging environment for HE graduates, who exhibited one of the lowest rates of employability and one of the highest rates of unemployment (OECD, 2011). Specifically, graduate employment started from a low base, but it then rose substantially, from $59,4 \%$ in 2005 to $68,3 \%$ in 2008. However, since 2009 it has been on a free fall and in 2013 it reached a low of $40 \%$. Although the situation has been improving since then, Greece still displays the lowest rate of graduate employment among the 28 EU member states: 47,4\% in 2014 compared to an average of $80,5 \%$ for the EU28 (European Commission, 2015: 7).

Furthermore, Greece has been grappling with persistent youth unemployment. Some progress achieved from the start of the new millennium was brought to an abrupt halt with the crisis. Specifically, between 2008 and 2014 Greece recorded both the highest youth unemployment, but also the steepest rise within that period among its EU counterparts (from around $23 \%$ in 2008 to over 53\% in 2014). In addition, Greece displays one of the highest and sharply amplified long-term unemployment rates among the OECD countries, from 49\% in Q4 2007 to $71 \%$ in Q1 2014 (OECD, 2014: 1). A discussed in section 3, youth and general unemployment rates would be even higher had it not been for emigration.

Notwithstanding the seriousness of the effects of the crisis on graduate employment prospects, as noted above, the Greek graduate labour market was riddled with flaws well before its onset. For example, graduate prospects were very uneven and dependent on type of $\mathrm{HE}$ institution ( $\mathrm{AEI}$ or $\mathrm{TEI}^{9}$ ) and degree subject obtained. For example, immediately before the crisis (2004-2007), natural sciences graduates were the worst affected by labour market shortages with over 35\% unemployment rate up to five years after graduation (followed closely by humanities and social sciences graduates, which are traditional female destinations). Conversely, law and computer science graduates were the least affected by unemployment (approximately $10 \%$ of them remained unemployed five years after graduation).

Low economic activity in Greece predates the crisis, especially for women (Papadopoulos, 2000). What is more, even those females in the labour market seemed to be at risk of losing their jobs at a much higher rate than their male counterparts. Although some variation in terms of employment practices and patterns is observed, the "female penalty" is a reality in nearly all Greek regions. For example, in the 2005-2008 period, this penalty "ranged between $5,1 \%$ in Athens and $12,6 \%$ in Western Macedonia" (Monastiriotis and Martelli, 2013: 20-21). The "female penalty" is also evident in relation to younger age groups. Specifically, female youth unemployment in 2016 stood at a staggering 51,4\% compared to
$41,3 \%$ for males (Eurostat, 2016) which points both to a wide gender gap and to alarmingly high rates of youth unemployment. While overall unemployment risk worsened for both males and females after the crisis, it can be safely deduced that, owing to the larger participation of males than females in the labour market, this risk increased for the former much more than it did for the latter. Hence, the labour market participation gender gap looks smaller than in the past. However, the focus here should be on the fact that both males and females were much more likely to lose their jobs in 2016 than they were in 2009 and not on the reduction of the unemployment risk gap between males and females.

If we combine the findings from the previous section, then we conclude that females are more educated but less employable than males. Apart from females, non-natives have also been associated with less favourable rates of entry into the labour market. Especially after the crisis, unemployment risk and general labour market position for non-native born workers worsened in most regions (Monastiriotis and Martelli, 2013).

\section{Returns on higher education qualifications}

Overall, Greek graduates display the lowest net returns on their educational qualifications in the EU (OECD, 2008). Although evidence is far from conclusive, recent studies indicate that "returns to education (in terms of employment probabilities) in the country, perhaps with the exception of Athens and Thessaloniki, remain even today rather low" (Monastiriotis and Martelli, 2013: 19). This trend further corroborates a pattern of precarity among $\mathrm{HE}$ graduates, despite the positive contribution of HE qualifications to wages (Cholezas and Tsakloglou, 1999; Magoula and Psacharopoulos, 1999; Prodromidis and Prodromidis, 2007). These results are in harmony with the trends discussed in section two and they further indicate that despite a wage premium HE holders might enjoy, this is not economically significant nor commensurate to the qualifications they hold.

Despite gender disparities favouring male graduates in the labour market, as discussed above, private average returns on education were higher for women than for men before the crisis (Cholezas and Tsakloglou, 2006; Papapetrou, 2006). Specifically, an undergraduate university degree (AEI) is associated with a $29 \%$ wage premium for females and a $24 \%$ premium for males (Livanos and Pouliakas, 2009). However, gender disparities increased after the crisis and differentials in earnings and occupational segregation are stark. The gender pay gap in 2013 stood at $15 \%$ (16,3\% in the EU28) (Eurostat, 2013) with women over-concentrated in areas of the economy with lower returns than men 
(Livanos and Pouliakas, 2012). This mirrors the less risky educational pathways women follow, such as humanities and education, which are characterised by the lowest wage returns.

Consistent with previous studies, a degree from a traditional university (AEI) is associated with a higher premium than one from a Technological Institution (TEI) (Livanos and Pouliakas, 2009). In addition, wage returns on first and post-graduate qualifications are higher in the private rather than in the public sector, though the reverse is the case for PhD degrees. Finally, private returns vary considerably depending on degree subject, with social sciences graduates enjoying the lowest rate of return ( $3,8 \%$ for males versus $6,2 \%$ for females). By contrast, languages graduates display the highest rates of return (9,9\% for males and $9,8 \%$ for females), followed by education graduates $(8,9 \%$ for males versus $9,9 \%$ for females).

In line with findings reported in the previous section about age differentials, inequalities in earnings point to an age-associated penalty that disadvantages those at a younger age. Admittedly this relates to experience, qualifications and on-the-job training rather than age per se and it is reversed with occupational maturity. A recent study ${ }^{10}$ reported that $71 \%$ of graduates aged $30-35$ years were employed in comparison to just $52 \%$ of $18-29$ year olds (kariera.gr, 2016). Income disparity is also prevalent between these two groups with $45,6 \%$ of the latter (18-29 year olds) earning less than 500 euros per month, compared to $21,3 \%$ of the former group (30-35 year olds). Conversely, a higher proportion $(47,6 \%)$ of $30-35$ year olds enjoyed an income of 851 euros per month or higher in comparison to only $21,4 \%$ for those aged $18-29$ years. Since the onset of the crisis, in-work poverty has increased significantly across age groups though there is a noticeable "shift in poverty from the old to the younger generations" (Koutsogeorgopoulou et al., 2014: 13), increasing thus the degree of precariousness of this age group.

Regarding poverty of the precariat, Greece displayed higher levels of poverty than the EU average across all educational categories both in 2009 and 2015. However, HE qualifications do offer some protection from poverty. For example, in 2015, at the height if the crisis, HE graduates were the least likely to be under the poverty line $(4,9 \%)$ in comparison to primary school graduates $(28,4 \%)$ who were adversely affected by the drop in the minimum wage and the rise in part-time employment that occurred after the crisis (Eurostat, 2016).

\section{Graduate destinations}

Given the rise in HE graduates (Section 1) amid increased uncertainty in terms of employment, career and labour market prospects (Section 2), what is the full extent of precarity and what the alternatives to it do Greek graduates explore? I discuss these issues in the remainder of this section.

\section{Skills mismatch of graduates ${ }^{11}$}

A rise in underutilization ${ }^{12}$ was registered between 2004 and 2010 in most EU countries (Cedefop, 2012). Over-qualifications and skills mismatch in graduate jobs ${ }^{13}$ was limited, that is to say applicable to $10 \%$ or less of graduates, only in a handful of countries (namely Germany, the Netherlands, Slovenia and Switzerland), which invariably put a strong emphasis on vocational training (CIPD, 2015). On the other hand, Greece recorded both the steepest increase and one of the highest rates of graduates in non-graduate jobs with $45 \%$ of them in 2004 found in jobs that required lower qualifications than they possessed. In 2010, this rate rose to almost $65 \%$, the second highest rate among the surveyed countries.

According to a different survey based on self-reporting of over-education in the labour market ${ }^{14}$ (Eurofound, 2010), an improvement in underutilization was registered for the majority of surveyed countries with less than $25 \%$ of graduates reporting underutilization in 2010 in comparison to 2005. However, in Greece (along with another nine countries $)^{15}$, underutilization was higher than $35 \%$. Despite the different methodology of the surveys reported above, the underutilization of Greek graduates is unquestionable.

Brain drain

Emigration of graduates, or "brain drain", is not a new not a uniquely Greek phenomenon. However, its upsurge after the crisis has given it dimensions of a socio-economic crisis in its own right. Apart from the obvious short and medium-term ramifications it has for the Greek society and economy, its long-term consequences are equally deleterious. While youth emigration contributes to a reduction in unemployment (see section 2 ), it has detrimental effects on the productive capacity of the country and its future prospects. Traditionally, Greek emigrants used to be 30 years old or younger, but with the onset of the crisis a larger than ever before proportion among them are older than 40 years old $(12 \%)$. Regarding the educational background of emigrants, a substantial upgrade has occurred over the last few decades Until the 1980s Greek emigrants on average used to hold primary or middle school certificate, while during the 1990 s they possessed high school diploma. Since the new millennium, they have been ever higher educated with $75 \%$ of them holding HE qualifications. This 
trend has persisted well into the 2010s (Labrianidis and Pratsinakis, 2016).

The number of Greeks aged 15-64 who emigrated since 2008 , is at least half a million people $(427,000)$ (Kathimerini, 2016). At the beginning of the crisis, the yearly average of Greek emigration was around 30,000 people. However, as the crisis deepened and unemployment kept soaring, emigration intensified and became the chief avenue to economic activity for the precariat. In 2013 alone, approximately 100,000 Greeks emigrated abroad. Figures for 2014 and 2015 point to comparable rates, making this wave of migration the third substantial and sustained one the country has experienced in its modern history ${ }^{16}$. In other words, the implications of the crisis for Greece are comparable to the major wars in which it participated during the $20^{\text {th }}$ century and which largely destroyed the country's infrastructure, productive capacity, economy and social fabric.

The motivations for moving abroad, the "pull" factors are mainly the pursuit of better working conditions, increased employment prospects and stability. On the other hand, the main "push factors" behind the Greek post-2008 emigration are unemployment, poor job prospects, low remuneration and relative deprivation (Triandafyllidou and Gropas, 2014), that is to say the ensemble of employment and labour market features that accompany precarity. For example, half of those who left Greece after 2010 were unemployed prior to emigration and a large proportion of them were economically inactive or underemployed for several months or years before emigration.

Arguably, the "brain-drain" has affected Greece for at least the last 100 years (Psacharopoulos and Tassoulas, 2004). For, there is another dimension to it, which has to do with student migration. Before the crisis Greece was one of the world's prime "exporters" of students to other countries, which has had a negative effect on the balance of payments and nurtured the "brain drain". Characteristically, "in 2007, proportional to its size, Greece had the highest proportion of students studying abroad in comparison to any other country in the world" (Themelis, 2013: 84). Despite the significant reduction in the relevant rates in comparison to the pre-crisis levels, there is still a high proportion of Greek students $(5,8 \%)$ who study abroad ${ }^{17}$. At any rate, student migration peaked in 2007, when it exceeded 51,000 students. Since then, it has been diminishing (22,000 students in 2012) (ICEF, 2013).

\section{NEETs ${ }^{18}$}

The amount of young people not engaged in any form of employment, education or training has increased due to the crisis in most EU countries with the notable exceptions of Germany, Sweden and the UK. Specifically, among the 15-24 year-old group, NEETs in the EU increased from 10,9\% in 2008 to $13 \%$ in 2013 (Eurofound, 2016). Since then, this rate has been falling steadily $(12 \%$ or 6.6 million young people in 2015) (Eurostat, 2015). However, large disparities exist among EU countries with the North displaying much better rates (e.g. 4,7\% in the Netherlands, 6,2\% in Denmark and Germany and $6,7 \%$ in Sweden) than the South (e.g. 15,6\% in Spain, $17,2 \%$ in Greece, $19,3 \%$ in Bulgaria and $21,4 \%$ in Italy).

In terms of gender, more females are NEETs than males in most EU countries. In 2000, the female-male gap among those aged 15-24 years was $3,4 \%$ although it subsequently dropped to 0,9 in 2011 (Eurofound, 2012) and 0,6\% in 2015 $5^{19}$.

In a host of South European countries, including Greece, the proportion of NEETs increased significantly since the onset of the crisis, together with youth unemployment. In 2008, $11,4 \%$ of all 15-24 year olds in Greece were classified as NEETs (Eurostat, 2016). This rate continued to rise until 2013 when it peaked at $20,4 \%$. Since then, is has been decreasing steadily and in 2015 it stood at $17,2 \%$ (Eurostat, 2016). In most EU countries, the rise of NEETs during the crisis is an outcome of the upsurge in youth unemployment rather than economic inactivity. In Greece, around $70 \%$ of NEETs were unemployed but active ${ }^{20}$ (European Commission, 2015). The broad characteristics of the Greek NEETs are as follows: more often than not female, between 20-24 years old, of Greek origin, medium to high educational attainment (including HE graduates), with some work experience, from low income families, without prior training programme attainment, supported by their family and often without social insurance (Drakaki et al., 2014).

Another key feature of the Greek NEETs is the higher than the EU average proportion of HE graduates among them. Specifically, more than a quarter of 15-24 years old NEETs are HE graduates, in contrast to most EU countries where a higher proportion of NEETS are low skilled (Eurofound, 2012). In addition, Greek NEETs in the same age group (15-24 years old), seem to come from low income families, which is associated with high rates of intergenerational transmission of poverty (see Papatheodorou and Papanastasiou, 2010). Evidently, higher education qualifications in Greece do not shield their holders from entering the NEET category, though they seem to offer some protection from poverty.

\section{Conclusion}

This paper discussed the transition from higher education into the labour market among young graduates, focusing on the period from approximately 
2000 to date. It identified a number of trends. First, this transition is protracted and not completed for the majority of graduates until their thirties. Second, the labour market is fragmented along education level, place of living (urban or non-urban), gender, age and ethnic lines. Third, higher education does not seem to play a socially integrative role, as it does not offer any shield against unemployment, emigration and precariousness. Fourth, the crisis has exacerbated enduring problems integral to higher education and its weak connections with the labour market. I will elaborate on these trends and offer some explanation.

During the crisis, the availability of highly skilled graduates intensified competition for the fewer jobs that were on offer as the public sector shrunk and the private did not recuperate the job losses it sustained due redundancies imposed by the lack of investment and reduced profitability. However, the traditional orientation of higher education towards the public sector (Kanellopoulos et al., 2003) did not alter accentuating therefore the mismatch between the production of graduates and the labour market capacity to absorb them (Karamessini, 2008; Liagouras et al., 2003). What is more, the crisis dismantled the foundations of the Greek labour market and created an attendant social crisis, which severely affects its highly educated youth and curtails their employment prospects.

However, in the Greek case at least, some caution has to be exercised in the explanatory power of the crisis as a set of chronic issues and difficulties, inherent within the Greek higher education system and the graduate labour market has been operating well before the crisis. These issues include low levels of degree completion, high graduate unemployment and low returns on education (OECD, 2008). In particular, the labour market has been a notoriously tough and unpredictable environment within which to operate and it has traditionally reserved low levels of economic activity, especially among females, very high rates of self-employment (Papadopoulos, 2000) and above average unemployment rates for university graduates (Livanos, 2010). Moreover, it has invariably allowed various barriers in its smooth and fair operation, such as clientelism, nepotism and lack of meritocracy (Themelis, 2013). The economy itself has been lacking in dynamism since the end of the Second World War as well as in investment in sectors with productive capacity. Moreover, it has customarily operated with short-termism in relation to economic and infrastructural planning, it has been traditionally displaying economic rigidities (Pagoulatos, 2003), dependency on the EU and external funding, and it has succumbed to the free market dogma without maintaining its distinctiveness and competitive advantages that could generate and sustain employment opportunities for the ever rising numbers of highly educated people. Furthermore, there has traditionally been a supply and demand problem in the skilled jobs market, which is more pronounced among females, non-native born people and those living outside the main urban centres. While emigration seems to offer some relief to the "opportunity-starved" young graduates, it also drains the country from talent and resources (Labrianidis and Pratsinakis, 2016).

To conclude, this paper has alluded to a key trend underpinning the interface between higher education and the labour market. As the number and proportion of qualified people increased significantly after the 1990s, their prospects diminished equally markedly. Before the crisis, Greece was losing out on talent and private capital as high demand for HE was not met by domestic institutions, thusly forcing the Greek family to fund their offspring studies abroad. However, high numbers of those highly educated and trained abroad would eventually return home in order to enter the labour market with better prospects. In this way, Greece seems to have benefited from a "brain gain" that lasted up until the onset of the crisis. Conversely, after the crisis demand for HE has been met by Greek institutions but Greece is now losing out both on talent who emigrate upon graduation but also on public capital in the form of HE expenditure foregone for those who emigrate abroad. This trend points to a significant "brain drain". At any rate, the multiple and overlapping problems underlying the transition from higher education to the labour market is at the crux of the economic and political problems Greece is facing and they point to a ticking bomb at the foundations of the Greek society.

\section{Notes}

1 Well above Italy (18\%), France (19\%), Portugal (23\%), Spain (24\%) and Germany (27\%), but below Finland $(30 \%)$, the Netherlands $(34 \%)$, Ireland $(34 \%)$, the UK (34\%) and Belgium (38\%).

${ }^{2}$ Averages need some caution, as they mask wide variation in national rates between high and low performers. On one hand, there is a handful of countries (namely Lithuania, Cyprus, Ireland, Luxembourg and the UK) with rates very close to or higher than the $50 \%$ threshold. On the other hand, another relatively small group of countries, including Germany, Czech Republic, Malta, Romania and Italy, are concentrated at or below the $30 \%$ mark. However, a majority of 17 countries including Greece, achieve a slightly higher than average rate than the EU.

${ }^{3}$ Italy (10,3\%), Spain (12,3\%) and Ireland (13,5\%) exhibited a higher attainment gap than Greece but close to the EU28 average, while Portugal $(16,9 \%)$ had a much higher gap.

${ }^{4}$ Refers to people aged 20-34 who left education between one and three years before the reference year.

${ }^{5}$ By $36 \%$ according to different sources (Hellenic Government, 2015). 
6 Consistent with findings from the two previous annual surveys conducted by the same organisation in 2014 and 2015, the three more important priorities young people set in terms of occupational selection are personal and professional development, remuneration and working environment. Expectedly, the majority of the respondents reported that the crisis has had a negative impact on their personal life and their perception of labour (kariera. gr, 2016).

7 What is more, working conditions in the public sector have deteriorated even in critical areas. For example, the situation in public hospitals has reached dangerously low levels, with long queues for patients, long working hours for professionals, often with minimal resources to operate or offer first aid, overcrowding of wards, and shortages of doctors, nurses and medical and paramedical personnel.

8 In all EU countries, apart from Malta, Denmark and Germany, youth unemployment increased during the crisis. In a handful of countries, youth unemployment sky-rocketed, most notably in Cyprus and Greece, but also in Italy, Spain, Portugal and Croatia.

9 Greek HE has two tracks. The first consists of the "AEIs" and is made up of the traditional universities, the so-called polytechnics (no remembrance with the British polytechnics), the Schools of Fine Art and the Open University. The second, "TEIs", consists of the Technological Education Institutions (TEI) and the School of Pedagogic and Technological Education.

10 This is an annual, national study which was last conducted in spring 2016 across a sample of over 5,000 18-35 year-old HE students and graduates.

11 Data on skills mismatch of graduates needs to be treated with some caution as it is based on two distinct methodologies.

12 Underutilization here is measured as years in education and is defined as graduates working in jobs that require lower qualifications than they possess. The latter, qualifications, are measured as years in education.

13 By "graduate jobs", it was meant jobs obtained after 15-16 years of education.

14 Surveys based on "objective indicators", such as years in education, do not take into account the upgrade in jobs over the years and variation in new graduates' qualifications in relation to market changes. Surveys based on "subjective indicators", such as self-reporting, rely on graduates' own assessment of skills required for the job they perform. While this measurement is not immune from shortcomings, such the usefulness of perceptions of skills as a comparable criterion, the culturally-varied meaning of underutilization and so on, it still provides some useful insights into graduates' own assessment of their own employment situation in relation to their qualifications.

15 These countries were Croatia, France, Hungary, Latvia, Luxembourg, Romania, Slovenia, Spain and the United Kingdom.

16 The other two namely, the 1903-1917 and the 19601972 ones, occurred after the First and Second World War respectively.

17 Approximately one in three of them chooses the UK and one in seven Germany.
18 NEETs are defined as those young people under 30 years old not engaged in employment, education or training.

19 Average rates disguise cross-country variation with some member states recording a 10\% gender gap. For example, in the Czech Republic, Malta, Germany, Hungary, Romania and the UK, approximately $55 \%$ of NEETs were women whereas in a handful of countries the same proportion of NEETs were men (i.e. Luxembourg, Finland, Croatia and Cyprus).

20 By contrast, in Bulgaria, Italy and Romania the majority of NEETs were inactive rather than unemployed.

\section{References}

CEDEFOP (European Centre for the Development of Vocational Training) (2011), Vocational Education and Training at Higher Qualification Levels, Luxembourg, Publications Office of the European Union. Retrieved from www.cedefop.europa.eu/ files/5515_en.pdf

CEDEFOP (European Centre for the Development of Vocational Training) (2012), Skill Mismatch: The Role of the Enterprise, Luxembourg, Publications Office of the European Union. Retrieved from www. cedefop.europa.eu/en/publications-and-resources/ publications/5521

CHOLEZAS, I. and P. Tsakloglou (1999), "Private Returns to Education in Greece: A Review of the Empirical Literature", in R. Asplund and P. T. Pereira (eds.), Returns to Human Capital in Europe: A Literature Review, ETLA, Helsinki.

CHOLEZAS, I. and P. Tsakloglou (2006), Gender Earnings Differentials in the Greek Labour Market, Athens University of Economics and Business, IMOP and IZA, Bonn.

CHRISTOPOULOU, R. and V. Monastiriotis (2016), "Public-Private Wage Duality During the Greek Crisis", Oxford Economic Papers, 68(1), pp. 174196. Retrieved from http://oep.oxfordjournals. org/content/68/1/174

CIPD (Chartered Institute of Personnel and Development) (2015), Over-Qualification and Skills Mismatch in the Graduate Labour Market (Policy report). Retrieved from https://www.cipd.co.uk/Images/ over-qualification-and-skills-mismatch-graduatelabour-market_tcm18-10231.pdf

DRAKAKI, M.; N. Papadakis; A. Kyridis and A. Papargyris (2014), "Who's The Greek Neet? Parameters, Trends and Common Characteristics of a Heterogeneous Group", International Journal of Humanities and Social Science, 4(6), pp. 240-254. Retrieved from http://www.ijhssnet.com/journals/ Vol_4_No_6_April_2014/26.pdf

EENEE (European Expert Network on Economics of Education) (2012), A Policy Agenda for Improving Access to Higher Education in the EU (EENEE Analytical Report No. 9). Retrieved from www.eenee. de/dms/EENEE/Analytical_Reports/EENEE_AR9.pdf

EUROFOUND (2010), European Working Conditions survey (EWCS), Luxembourg, Publications Office of the European Union. Retrieved from https:// www.eurofound.europa.eu/surveys/european- 
-working-conditions-surveys/fifth-european-working-conditions-survey-2010

EUROFOUND (2012), NEETs - Young People Not in Employment, Education or Training: Characteristics, Costs and Policy Responses in Europe, Luxembourg, Publications Office of the European Union.

EUROFOUND (2016), Exploring the diversity of NEETs, Luxembourg, Publications Office of the European Union. Retrieved from https://www.eurofound. europa.eu/sites/default/files/ef_publication/ field_ef_document/ef1602en.pdf

EUROPEAN COMMISSION (2015), Employment and Social Developments in Europe, Luxembourg, Publications Office of the European Union. Retrieved from http://ec.europa.eu/social/keyDocuments. jsp?advSearchKey=Employment+and + Social $+D$ evelopments+in+Europea $+2014 \&$ mode $=$ advanc edSubmit\&langId $=$ en\&policyArea $=\&$ type $=0 \&$ cou ntry $=0$ \&year $=0$

EUROPEAN PARLIAMENT (2013), The Social and Employment Situation in Greece, Brussels, European Union. Retrieved from http://www.europarl.europa. eu/RegData/etudes/note/join/2013/507491/IPOL-EMPL NT(2013)507491_EN.pdf

EUROSTAT (2013), The Gender Pay Gap in Greece. Retrieved from http://ec.europa.eu/justice/genderequality/gender-pay-gap/index_en.htm

EUROSTAT (2015), Unemployment Statistics. Retrieved from http://ec.europa.eu/eurostat/statisticsexplained/index.php/Unemployment_statistics

EUROSTAT (2016), Harmonised Unemployment Rate by Sex - Age Group 15-24. Retrieved from http:// ec.europa.eu/eurostat/tgm/refreshTableAction. do?tab $=$ table\&plugin $=1 \&$ pcode $=$ teilm021\&lang uage $=$ en

HELLENIC GOVERNMENT (2015), National Reform Programme (NRP) for 2015. Retrieved from http://ec.europa.eu/europe2020/pdf/csr2015/ nrp2015_greece_el.pdf

KANELLOPOULOS, K.; K. Mavromaras and T. Mitrakos (2003), Education and the Labour Market, Athens, KEPE (in Greek).

KARAMESSINI, M. (2008), The Absorption of University Graduates in the Labour Market, Athens, Network of the Career Offices of Universities and Dionicos (in Greek).

KARIERA.GR (2016), Career and Generation Y. Retrieved from http://www.careerguide.gr/career-geny/

KATHIMERINI (2016, 20, 07), Brain Drain Amounted to 223,000 People in 2008-2013. Retrieved from http://www.ekathimerini.com/210626/article/ ekathimerini/business/brain-drain-amounted-to-223000-people-in-2008-2013

KOUTSOGEORGOPOULOU, V.; M. Matsaganis; C. Leventi and J. D. Schneider (2014), Fairly Sharing the Social Impact of the Crisis in Greece (OECD Economics Department Working Papers, No. 1106). DOI: http://dx.doi.org/10.1787/5jzb6vwk338x-en

LABRIANIDIS, L. and M. Pratsinakis (2016), Greece's New Emigration at Times of Crisis, Hellenic Obser- vatory Papers on Greece and Southeast Europe, London, (99), pp. 1-48. Retrieved from http:// eprints.Ise.ac.uk/66811/1/GreeSE-No.99.pdf

LIAGOURAS, G.; A. Protogerou and Y. Kalogirou (2003), "Exploring Mismatches Between Higher Education and the Labour Market in Greece", European Journal of Education, 38(4), pp. 413-26.

LIVANOS, I. (2010), "The Wage-Local Unemployment Relationship in a Highly Regulated Labour Market: Greece", Regional Studies, 44(4), pp. 389-400.

LIVANOS, I. and K. Pouliakas (2009), The Gender Wage Gap as a Function of Educational Degree Choices in Greece (MPRA Working Paper, No. 14168). Retrieved from https://mpra.ub.uni-muenchen. de/14168/

LIVANOS, I. and K.. Pouliakas (2012), "Educational Segregation and the Gender Wage Gap in Greece", Journal of Economic Studies, 3(5), pp. 554-575. DOI: https://doi.org/10.1108/01443581211259473

MAGOULA, T. and G. Psacharopoulos (1999), "Schooling and Monetary Rewards in Greece: An OverEducation False Alarm?", Applied Economics, 31(12), pp. 1589-1597.

MONASTIRIOTIS, V. and A. Martelli (2013), Beyond Rising Unemployment: Unemployment Risk, Crisis and Regional Adjustments in Greece (GreeSE Paper 80). Retrieved from http://www.Ise.ac.uk/europeanInstitute/research/hellenicObservatory/CMS\%20 pdf/Publications/GreeSE/GreeSE-No80.pdf

OECD (2008), Education at a Glance 2008. Retrieved from https://www.oecd.org/education/skills-beyond-school/41284038.pdf

OECD (2011), Education at a Glance 2011. DOI: http:// dx.doi.org/10.1787/eag-2011-en

OECD (2013), Education at a Glance 2013. DOI: http:// dx.doi.org/10.1787/eag-2013-en

OECD (2014), OECD Employment Outlook 2014. Retrieved from https://www.oecd.org/employment/emp/ EMO-GRC-EN.pdf

OECD (2015), Education at a Glance 2015. DOI: http:// dx.doi.org/10.1787/eag-2015-en

PAgOULATOS, G. (2003), Greece's New Political Economy: State, Finance, and Growth from Postwar to $E M U$, New York, Palgave Macmillan.

PAPADOPOULOS, T. (2000), Integrated Approaches to Active Welfare and Employment Policies: Greece, European Foundation for the Improvement of Living and Working Conditions.

PAPAPETROU, E. (2006), "The Unequal Distribution of the Public-Private Sector Wage Gap in Greece: Evidence from Quantile Regression", Applied Economics Letters, 13(4), pp. 205-210. DOI: https:// doi.org/10.1080/13504850500393063

PAPATHEODOROU, C. and S. A. Papanastasiou (2010), Intergenerational Transmission of Poverty in Greece and the EU: Theoretical Approaches and Empirical Analysis, Greece, INE/GSEE (in Greek).

PRODROMIDIS, K. P. and P. I. Prodromidis (2007), "Returns to Education: The Greek Experience, 1988- 
1999", Applied Economics, 40(8), pp. 1-8. DOI: https://doi.org/10.1080/00036840600771197

PSACHAROPOULOS, G. and S. Tassoulas (2004), "Achievement at the Higher Education Entry Examinations in Greece: A Procrustean Approach", Higher Education, 47(2), pp. 241-252.

STANDING, G. (2011), The Precariat: The New Dangerous Class, London, Bloomsbury Academic.

THEMELIS, S. (2013), Social Change and Education in Greece: A Study in Class Struggle Dynamics, New York, Palgrave Macmillan.
TRIANDAFYLLIDOU, A. and R. Gropas (2014), "'Voting with their Feet': Highly Skilled Emigrants from Southern Europe", American Behavioral Scientist, 58(12), pp. 1614-1633. DOI: $10.1177 / 0002764214534665$

ZAHARIADIS, N. (2014), "Powering Over Puzzling? Downsizing the Public Sector During the Greek Sovereign Debt Crisis", Journal of Comparative Policy Analysis: Research and Practice, 18(5), pp. 464-478. DOI: http://dx.doi.org/10.1080/13876 988.2013.861971

Recebido a 27/07/2017. Aceite para publicação a 15/12/2017.

Spyros Themelis (s.themelis@uea.ac.uk). University of East Anglia, School of Education and Lifelong Learning. Lawrence Stenhouse Building, Room 15.1, Norwich Research Park, Norwich, NR4 7TJ, UK. 